\title{
(P) DERECHE \\ Cuestiones procesales de la gestión preparatoria de notificación de facturas
}

\section{Procedural issues related to the preparatory acts for the formal no- tice of an invoice}

\section{Gonzalo Santini Zañartu' (D) https://orcid.org/0000-0001-9784-0185 \\ 'Universidad de los Andes, Las Condes, Chile. Profesor instructor de Derecho Civil. Abogado. Candidato a Magister en derecho (LLM) en la University College London.

gsantini@uc.cl

Resumen:

Se analiza la situación procesal en que se encuentra el deudor de una factura tras la notificación judicial que contempla la Ley $N^{\circ} 19.983$, que regula la transferencia y otorga mérito ejecutivo a copia de la factura, en vigor desde el 15 de diciembre de 2004. En concreto, analiza el sentido y alcance de su artículo $5^{\circ} \mathrm{d}$ ) - que trata la denominada "gestión preparatoria de notificación de facturas"- a la luz de las diversas modificaciones legales de la Ley $N^{\circ} 19.983$, el análisis doctrinario y la prolífera y disonante jurisprudencia de los tribunales superiores de justicia chilenos. En el cumplimiento de este objetivo, se revisa la doctrina nacional y se proponen soluciones a diferentes entendimientos de nuestros tribunales superiores de justicia, sobre: (i) la naturaleza jurídica de la gestión preparatoria de notificación de facturas y las consecuencias procesales que de ella se derivan; (ii) las defensas del obligado al pago de una factura frente al emisor y cesionario de la misma; y (iii) la carga procesal de las partes en caso de impugnación de una factura. Para finalizar, se proponen algunas conclusiones.

Palabras Clave: Cobro de facturas; Impugnación de facturas; Excepciones.

\begin{abstract}
:
The procedural situation in which the debtor of an invoice is found is analyzed after the judicial notification contemplated by Law No. 19.983, which regulates the transfer and grants executive merit to a copy of the invoice, in force since December 15, 2004. In particular, the paper reviews the meaning and scope of article $5^{\circ} \mathrm{d}$ ), which regulates the preparatory acts for the formal notice of an invoice, regarding the position of Chilean authors and the different legal amendments of Law $N^{\circ} 19.983$ and the prolific and dissonant jurisprudence of Chilean high Courts of Justice. In achieving this objective, this study reviews the opinion of Chilean authors and the possible solutions to different understandings of our superior Courts with respect to: (i) the legal status of the preparatory proceeding of the invoice judicial notification and the procedural consequences that are derived from it; (ii) the defense of the debtor against the issuer and the assignee of an invoice; (iii) the procedural burden of the parties in the case of a challenge to the invoice. Finally, some conclusions are proposed. Keywords: Invoice collection; Challenge of invoices; Defenses
\end{abstract}




\section{Introducción}

El artículo 5 de la Ley $N^{\circ} 19.983$ (2004), que regula la transferencia y otorga mérito ejecutivo a copia de la factura, exige para otorgarle mérito ejecutivo a su copia: (a) que la factura no haya sido reclamada en los términos del artículo $3^{\circ 1}$; (b) que su pago sea actualmente exigible, y la acción para su cobro no esté prescrita; (c) que conste en ella el recibo de la entrega de la mercadería o de la prestación del servicio, con las indicaciones establecidas en la ley para individualizar al comprador o beneficiario del servicio o de la persona que recibe la mercadería o servicio; y (d) que le sea notificada judicialmente al obligado, sin su oposición, o en caso de haberla, que su defensa sea rechazada por resolución judicial. Esta última disposición configura lo que se ha denominado como la gestión preparatoria de la vía ejecutiva y que consiste en la notificación judicial de la factura o de su copia, oportunidad en que la ley habilita al obligado al pago a oponerse a éste.

En la jurisprudencia no existe consenso sobre qué es la gestión preparatoria de notificación de facturas, ni de las consecuencias procesales que derivan de ello. Asimismo, los fallos judiciales también difieren sobre las defensas que puede esgrimir el notificado del cobro durante su oposición. Respecto de esto último, y en lo que interesa para este estudio, existen diversas interpretaciones sobre en qué consiste la impugnación de una factura por la falta de entrega de la mercadería o la falta de prestación del servicio que contenía la Ley $N^{\circ} 19.983$ (2004) hasta su modificación mediante la Ley $\mathrm{N}^{\circ} 20.956$ (2016).

Como se verá, la importancia de establecer la situación procesal y el alcance de la defensa o impugnación del obligado al pago, radica en que la factura es un título de cobro cuyo origen depende de la voluntad del acreedor y en la que, en principio, no participa el deudor; por lo que la amplitud que se otorgue al mecanismo de impugnación a que puede recurrir el deudor determinará, en definitiva, su forma de participación en la creación del título ejecutivo.

En este estudio se analizan las modificaciones a la ley y los problemas que ha generado en el entendimiento divergente del tribunal chileno superior de justicia, particularmente, respecto de la naturaleza jurídica de la gestión preparatoria de notificación de facturas, y de la defensa del deudor para impugnar una factura. Para ofrecer una solución a ello, se recurre a la postura de distintos autores nacionales. Finalmente, se proponen algunas conclusiones.

\footnotetext{
${ }^{1}$ Dicha reclamación puede realizarse: (1) Devolviendo la factura o la guía de despacho al momento de su entrega; o (2) Reclamando contra su contenido en el plazo y forma que establece la ley.
} 


\section{Naturaleza jurídica de la gestión preparatoria}

La factura es uno de aquellos títulos que nuestra doctrina ha denominado "ejecutivos imperfectos", por cuanto requieren previo a la ejecución, de un procedimiento o gestión preparatoria. La gestión preparatoria de la vía ejecutiva de este instrumento importa una notificación de la factura al obligado al pago, gestión cuya naturaleza jurídica ha sido controvertida tanto por nuestra doctrina como jurisprudencia. Como se verá, dependiendo de la solución que se tome, esto es, si la gestión preparatoria es una "mera gestión" o un "juicio propiamente tal", fluyen diversas consecuencias procesales, que se pasan a revisar.

\subsection{La gestión preparatoria y la resolución que la resuelve}

Como cuestión preliminar, cabe considerar que la discusión sobre la relación entre la gestión preparatoria de la vía ejecutiva y el juicio ejecutivo -esta es, de independencia o unidad- no es reciente en nuestro derecho, según notó Salas Vivaldi (1986) en un comentario a una sentencia de la Iltma. Corte de Apelaciones de Concepción de 1986.

Siguiendo a Salas Vivaldi (1986, p. 88), la tesis que sostiene la independencia entre los procedimientos se fundaría positivamente en los artículos 435 y 436 del Código de Procedimiento Civil (Ley N $\left.{ }^{\circ} 1.552,1902\right)$, toda vez que tales artículos distinguen entre las actuaciones realizadas con el propósito de preparar la ejecución y el juicio mismo, cuyo objeto es el cumplimiento forzado de la obligación; en el inciso primero del artículo 465, que permite oponer en el juicio ejecutivo la excepción de incompetencia del tribunal, no obstante haber actuado el presunto deudor en la gestión preparatoria -sin que haya operado la prórroga de la competencia-, lo que equivaldría a diferenciar ambos procedimientos; así como en el Código Orgánico de Tribunales (Ley $N^{\circ} 7.421,1943$, art. 178), que otorga al juez que haya conocido la gestión preparatoria la competencia para conocer del juicio ejecutivo, sin que tenga que aplicar la norma de distribución de las causas del antiguo artículo 176 de la Ley $\mathrm{N}^{\circ}$ 7.421 (1943) -con ello se refiere Salas Vivaldi (1986) a la tesis que afirma que “...si el legislador requirió dictar una norma expresa que unificara la competencia de un juez para conocer de ambas materias, lo fue porque estima que constituyen entidades distintas..." (p. 89); y sin la norma, habrían sido conocidas por tribunales distintos según las reglas de la competencia-; y así lo explicaría la historia del actual artículo 435 de la Ley $N^{\circ}$ 1.552, que demuestra que “...tanto para el Proyecto Lira como para la Comisión Revisora de aquél, las gestiones preparatorias fueron concebidas como actuaciones ajenas al juicio ejecutivo" (Salas Vivaldi, 1986, p. 89). Destaca Salas Vivaldi (1986, p. 89) que el artículo 405 establecía que la preparación de la vía ejecutiva a través del reconocimiento de firma y la confesión de deuda se realizarían según las normas de los medios de prueba del juicio ordinario, lo que confirmaría su independencia al juicio ejecutivo posterior; y que si bien la Comisión Revisora fue de la opi- 
nión que ambos mecanismos no debían regirse por las normas comunes, se desprende de las actas que le dieron carácter diligencias distintas del juicio ejecutivo.

Más recientemente, Rabat Celis (2002, pp. 111-112) ha sostenido que la gestión preparatoria de la vía ejecutiva constituye un juicio especial de naturaleza declarativa -y por lo tanto, distinto del juicio ejecutivo mismo- tal como se desprendería del artículo 435 citado. Según dicho artículo, el acreedor que carece de un título ejecutivo, pero que se encuentra en posesión o provisto de un principio de prueba por escrito, puede optar: (a) por un procedimiento ordinario declarativo; o (b) por el juicio especial previsto en el artículo 435 de la Ley $N^{\circ} 1.552$ (1902). Además, argumenta que la misma Ley $N^{\circ} 1.552$ (1902) reguló la gestión preparatoria dentro de su Libro III "De los Juicios Especiales". En sustento de su tesis recurre, asimismo, a la historia de la ley, la que daría cuenta que las gestiones preparatorias de la ejecución se regían por la Ley de Juicios Ejecutivos, de 1837; y por el Decreto de 4 de abril de 1837, que regulaba el procedimiento aplicable al caso en que la persona que debía reconocer documentos en juicio no podía comparecer ante el juez, norma que tenía aplicación general para toda clase de juicios y, especialmente, a la gestión preparatoria de la vía ejecutiva (Rabat Celis, 2002, p. 111).

A su turno, Casarino Viterbo (2007, p. 52; en términos similares, Romero Seguel, 2009, p. 67) era de la opinión de que las gestiones preparatorias de la vía ejecutiva forman parte de la llamada teoría general de las medidas prejudiciales -medidas distintas a aquellas del título IV del libro II de la Ley $N^{\circ} 1.552$ (1902)-, las que no tienen naturaleza de una "verdadera" demanda, por cuanto son gestiones preparatorias al juicio mismo; $y$, nuevamente, diferentes al juicio ejecutivo que las sucederá. A propósito, el autor sostiene sobre estas gestiones preparatorias que no tienen elementos distintivos de toda demanda, como son, la interrupción de la prescripción o la constitución en mora del deudor, salvo excepcionalmente, como ocurre con una demanda judicial de cobro de una letra de cambio o pagaré según la Ley $\mathrm{N}^{\circ} 18.092$ (1982, art. 100, inc. 1), que dicta nuevas normas sobre letra de cambio y pagaré (Casarino Viterbo, 2005, p. 202). Y es por ello que, coherentemente, concluye que es una sentencia interlocutoria la que da por reconocida la firma del deudor por falta de comparecencia o por haber dado respuestas evasivas, ya que resuelve un trámite que sirve para el pronunciamiento de una sentencia definitiva, cual es, la que recaerá en el juicio ejecutivo (Casarino Viterbo, 2007, p. 54).

Como se evidencia, si bien parece no haber mayor discusión respecto a que la "gestión preparatoria" es una vía de preparación de la ejecución distinta de ella, sí la hay sobre qué sería la gestión preparatoria de la vía ejecutiva -y, en lo que importa a este estudio, qué sería la gestión preparatoria de notificación de facturas-, por cuanto para unos es un trámite judicial sometido a las reglas de los incidentes, mientas que para otros, un juicio propiamente tal. 
En lo que se refiere a la gestión preparatoria de notificación de facturas, en doctrina se ha sostenido que ésta es un juicio. Cortéz Matcovich (2003, p. 52) afirma sobre la oposición del deudor mediante la impugnación a la factura que es ésta el objeto del proceso y sobre la cual deberá resolver el tribunal. De esta forma, es el deudor quien formula una pretensión de impugnación, asumiendo el acreedor el rol de sujeto pasivo o demandado. En otras palabras, siguiendo a este autor y de conformidad a la Ley N 1.552 (1902, art. 158), la oposición a la gestión preparatoria es un juicio.

Señala el autor que las razones para afirmar que existe una sentencia definitiva, y por lo tanto, un juicio, son: (i) que el objeto del juicio, esto es, la oposición, es una contienda jurídica en torno a la creación de un título ejecutivo; (ii) que no impide lo anterior que el procedimiento se encuentre sometido a tramitación incidental; y (iii) que la apelación contra la sentencia definitiva se conceda en efecto devolutivo, porque si la resolución que resuelve el procedimiento fuera una sentencia interlocutoria, no habría sido necesario decirlo (Cortéz Matcovich, 2003, p. 52).

Continúa Cortéz Matcovich (2003, p. 52) señalando que, entre las razones dadas para negar que sea un juicio propiamente tal, se encuentran: (i) que la Ley $\mathrm{N}^{\circ}$ 19.983 (2004) señala expresamente que "La impugnación se tramitará como incidente..." (art. $5^{\circ}$, letra d). En palabras de la Corte Suprema, en su sentencia del 7 de mayo de 2013, que:

No obstante tener la preparación de la vía ejecutiva un carácter contencioso, no constituye en sí misma un litigio propiamente tal, ya que sólo tiene por objeto llevar a efecto la diligencia previa solicitada en ésta, como por ejemplo la confesión de deuda, el reconocimiento de firma, etc., sin que puedan discutirse en ella otras materias. El verdadero pleito lo constituye el juicio ejecutivo del cual la diligencia preparatoria es sólo el antecedente (citado por Prado Puga, 2016, nota al pie 99)

y (ii) que el inciso segundo del artículo $5^{\circ}$ letra d) una vez más lo reafirma al establecer una sanción al que "...sea vencido totalmente en el incidente respectivo..." (Ley $N^{\circ} 19.983,2004$, art. 5. d).

Por su parte, la jurisprudencia de los tribunales nacionales no es conteste, e incluso hay fallos que han reconocido expresamente que la resolución que falla la gestión preparatoria es la sentencia definitiva de un juicio, porque "...es innegable que en virtud de ella se pone fin a la instancia, resolviendo la cuestión o asunto que ha sido objeto de ese juicio en particular, independientemente de la tramitación incidental que les atañe" (Banco Ripley con Ready Mix Sur S.A., 2011, cons. 16; entre otros, Resolución N 170420, 2013, cons. 5 y 6; Resolución № 15456, 2014, cons. 3).

Nos parece que la propuesta formulada por Salas Vivaldi (1986) años atrás, al analizar la naturaleza jurídica de la gestión preparatoria de la vía ejecutiva, soluciona 
la controversia de la naturaleza jurídica de la gestión preparatoria de la notificación de la factura, no obstante haber sido dictada la Ley $N^{\circ} 19.983$ (2004) años después del estudio del autor.

Salas Vivaldi (1986, p. 90), siguiendo al italiano Enrico Redenti, constata que para la ejecución forzosa de la obligación el acreedor debe comenzar por deducir una acción de cognición para procurarse de una sentencia de condena o de otro antecedente indubitado en razón de su origen judicial. Así, distingue entre la acción declarativa -que tiene por objeto, ya sea, una sentencia definitiva que ordene la satisfacción de una obligación cuya existencia se reconoce, ya la creación de otro antecedente que dé cuenta de la existencia de la obligación y que no tenga la naturaleza de sentencia definitiva condenatoria- y la acción ejecutiva -cuyo objeto es la obtención forzada del cumplimento de la prestación indubitadamente constatada en la acción declarativa que le antecedió-.

Con ello, coherentemente, concluye el autor que este carácter de acción declarativa cuyo objeto es la obtención de un antecedente indubitado de origen judicial, es común a las gestiones preparatorias de confesión de deuda; de reconocimiento de firma de los artículos 434 y 435 de la Ley Nº 1.552 (1902); y la Ley No 18.092 (1982), sobre letra de cambio y pagaré, que da cuenta de una instancia que terminará con un procedimiento judicial reconociendo la falsedad o autenticidad de la firma indubitada, en cuyo caso este último, dará origen a un título ejecutivo bajo reconocimiento de cosa juzgada (Salas Vivaldi, 1986, p. 91).

Finalmente, y recurriendo a la analogía, el citado autor descarta que la tramitación incidental contenida en la Ley № 18.092 (1982, art. 111), sobre letra de cambio y pagaré, para el caso de tacha de la firma estampada en los documentos, dé a la gestión preparatoria un carácter incidental, sustentando su tesis en los procedimientos autónomos de demanda de cobros de honorarios, las tercerías de pago y de prelación, que el legislador sometió a tramitación incidental, según los artículos 521 y 697 de la Ley $N^{\circ} 1.552$ (Salas Vivaldi, 1986, p. 91). Consecuencialmente, el autor sostiene que no comparte

...la opinión manifestada en algunos fallos en el sentido de considerar las gestiones a que da lugar la preparación de la vía ejecutiva como actos judiciales no contenciosos (Rev. Derecho y Jurisprudencia Tomo LXXXII 2a part. Sec. 1a, pág. 41). No vacilamos en reiterar que se tratan de verdaderos juicios cuya finalidad es la creación de un título ejecutivo y que se originan por una pretensión del acreedor dirigida en contra del deudor. (Salas Vivaldi, 1986, p. 92)

Remontándose así a los orígenes judiciales de la gestión preparatoria en Roma y luego en España. Al respecto, afirma Salas Vivaldi (1986, p. 92) que en caso de concluirse que sería un asunto no contencioso, conocería del mismo y de su ejecución el juez de letras del domicilio del acreedor, y el de turno, en lugares asiento de 
Corte de Apelaciones en que hubiere más de uno; no cabría considerar el fuero de las partes; no habría lugar a la prórroga de la competencia; todo según los artículos 133, 134, 179 y 189 de la Ley No 7.421 (1943). Y en materia probatoria, serían aplicables las normas de las informaciones sumarias; el tribunal podría decretar de oficio medidas informativas y las apreciaría prudencialmente; cuyas resoluciones, en casos, serían susceptibles del recurso especial de reconsideración; la intervención del deudor haría contenciosa la gestión; ello según los artículos 818, 819, 820, 821 y 823 de la Ley $\mathrm{N}^{\circ}$ 1.552 (1902), cuestiones todas alejadas de la práctica procesal, a juicio del autor.

Creemos que, en el caso particular de la gestión preparatoria de notificación de facturas, se dan los elementos para concluir que sí existe un procedimiento cuyo objeto, en caso de impugnación de facturas, así como la actividad de las partes, evidencian un conflicto de relevancia jurídica, en palabras de la Corte Suprema de

... un procedimiento controversial que da cuenta de un conflicto, en que los intereses de las partes involucradas están en contraposición, adquiriendo cada una de ellas las entidades legales de demandante y demandado. Es así como a través de este procedimiento se reúnen los elementos de un juicio, aun en su acepción más restringida, pretendiendo al demandante mejorar su propia condición en perjuicio de la del demandado o presunto deudor, sometiendo el asunto a conocimiento o decisión del juez competente. (Soc. de Transp. Latino Kunstmann Ltda. con Soc. Frutos del País Frías y Quera Ltda., 2010, cons. 9)

Con razón, tempranamente se advirtió en la discusión de la ley que a partir de la letra d) del $5^{\circ}$ artículo de la Ley $\mathrm{N}^{\circ} 19.983$ (2004), las cuestiones que se susciten serían asuntos "judiciales" (Historia de la Ley N¹9.983, 2018, p. 109).

\subsection{Consecuencias de determinar la naturaleza jurídica de la gestión pre- paratoria}

Saltan a la vista las diferentes consecuencias que se siguen de optar por una u otra alternativa respecto a la naturaleza de la gestión preparatoria de notificación de facturas, y quizás la más importante, la que se refiere a la reacción del deudor durante la gestión, manifestada en las defensas con que cuenta, así como la impugnación de la sentencia que resuelve la oposición al cobro de la factura.

\subsubsection{Defensa del deudor en juicio y recursos contra la sentencia de término}

En el entendimiento que la gestión preparatoria de notificación es un juicio y de naturaleza declarativa, forzosamente, cabe cuestionarse las soluciones legislativas que han pretendido denegar casi por completo la posibilidad del deudor de defenderse mediante la supresión de ciertos medios de impugnación de la factura.

En efecto, las distintas reformas a la Ley $N^{\circ} 19.983$ (2004) han ido restringiendo las defensas que puede hacer valer el deudor para impugnar el título: actualmen- 
te, tras la modificación de la Ley N 20.956 (2016, art. 5, d), sólo permite alegar la falsificación de la factura. No obstante, la Ley Nº 19.983 (2004) permitía desde su dictación impugnar el título, además, por la falta de entrega de la mercadería o prestación del servicio.

Ahora bien, si como se verá más adelante, dichas alegaciones referidas a la falta de entrega o prestación de los bienes de la factura se refieren a la validez del título mismo ¿qué sentido tuvo el legislador en mente para excluirlas de la gestión preparatoria? El objetivo de las modificaciones legales ha sido fortalecer la transferencia de facturas y proteger al adquirente -objetivo más económico que jurídico-, finalidad que -creemos- no logra la pretendida protección, por cuanto el deudor podrá deducir las mismas defensas durante el juicio ejecutivo, incrementando la incertidumbre del acreedor.

En efecto, veremos luego que la falta de entrega de la mercadería o de prestación de los servicios fundan la falta de objeto de la relación jurídica que subyace a la factura, cuestión que podrá alegarse en un juicio ejecutivo de conformidad a la Ley № 1.552 (1902, art. 464). Es decir, más que una solución para el adquirente de una factura, es una postergación de la discusión.

De todos modos, el Excmo. Tribunal Constitucional tuvo oportunidad de analizar la constitucionalidad de la restricción de las defensas del deudor que efectuó la última modificación a la Ley $N^{\circ} 19.983$ (2004), reconociendo su conformidad con el texto político. En palabras del Excmo. Tribunal Constitucional

De esta forma, la restricción en la oposición de excepciones personales, no es discriminatoria, sino que obedece a la decisión legislativa fundada y razonable, para constituir un título circulatorio con suficiente fuerza ejecutiva y facilitar la circulación del crédito que contiene, en la cual esta Magistratura no puede intervenir. (Requerimiento de inaplicabilidad por inconstitucionalidad presentado por el Servicio de Salud del Libertador General Bernardo O'Higgins, 2020, cons. 49)

y

Que, en el caso concreto el hecho de tener la factura mérito ejecutivo o de simplemente darle curso a una demanda ejecutiva no deja en un plano de indefensión al requirente, pues queda habilitado para que en el contradictorio del juicio ejecutivo oponga las excepciones que el Código de Procedimiento Civil establece en el artículo 464, con la limitación prevista a propósito de las excepciones personales... (Requerimiento de in- 
aplicabilidad por inconstitucionalidad presentado por el Servicio de Salud del Libertador General Bernardo O'Higgins, 2020, cons. 60) ${ }^{2}$

A su turno, y en lo que al régimen recursivo se refiere, si bien la procedencia del recurso de apelación contra la resolución que falla la gestión preparatoria viene resuelta por la misma ley (al concederlo en el efecto devolutivo), no existe consenso sobre la procedencia del recurso de casación. En este sentido, ciertos fallos son del parecer de la inadmisibilidad del recurso de casación, por cuanto la resolución que falla una impugnación no sería una sentencia definitiva ni una interlocutoria que ponga término al juicio o haga imposible su continuación; mientras otros sustentan su admisibilidad fundada en la naturaleza judicial que reviste la gestión preparatoria. En este último entendido, nuestros tribunales han declarado la admisibilidad de la casación contra la sentencia que resuelve la gestión preparatoria de notificación de facturas reconociendo expresamente que esta resolución reviste del carácter de sentencia definitiva (para lo resuelto por la Corte Suprema ver; Banco Ripley con Ready Mix Sur S.A., 2011, cons. 16; en el mismo sentido, Resolución $\mathrm{N}^{\circ}$ 544898, 2015), cuestión que en nuestra doctrina es compartida por los mismos autores analizados anteriormente. Al referirse a la resolución que resuelve una gestión preparatoria, Salas Vivaldi (1986, p. 91) concluye que es una sentencia que, una vez firme, da término definitivo a la instancia y produce cosa juzgada (en el mismo sentido, Rabat Celis, 2002, p. 112).

Por lo anterior, definida la naturaleza judicial de la factura según se vio en el capítulo anterior, creemos que procede la interposición del recurso de casación contra la sentencia que falla la gestión preparatoria; y son cuestionables, además, las soluciones legislativas cuyo objeto ha sido restringir la procedencia de ciertos medios de impugnación de la factura, sobre lo que se volverá más adelante.

\subsubsection{Otros efectos procesales}

Por otro lado, la discusión ha generado también controversia en sede procesal respecto a la posibilidad de alegar el abandono del procedimiento en el marco de una gestión preparatoria, como igualmente sobre el cómputo del plazo del abandono.

De hecho, mientras en ocasiones nuestros tribunales han aceptado la tesis de negar el incidente, por ejemplo, porque las gestiones preparatorias a la ejecución no serían un juicio propiamente tal y, por tanto, no son consideradas para un posible abandono del procedimiento (Resolución № 27.342, 2003, cons. 2), en otros casos se ha conocido el incidente, pero fundado en cuestiones accesorias, como es, a quién le correspondía el impulso procesal y no la naturaleza del procedimiento (Resolución $\mathrm{N}^{\circ}$ 8114,2016 , cons. 6).

\footnotetext{
${ }^{2}$ Eso sí, conviene notar que el Tribunal razona considerando que la factura es un título abstracto y que las defensas de falta de entrega de la mercadería o prestación del servicio son excepciones de naturaleza "personal", lo que no se comparte según se demuestra en este estudio.
} 
La procedencia del incidente dependerá, nuevamente, de la tesis que se siga. Así, en la doctrina revisada se ha afirmado que el incidente en cuestión está recogido en las disposiciones comunes a todo procedimiento, teniendo aplicación general salvo en cuanto la ley lo prohíba, lo que es concordante con la aplicación general del procedimiento ordinario según mandata la Ley $\mathrm{N}^{\circ} 1.552$ (1902, art. 3) (Rabat Celis, 2002, p. 117). Por ello, se concluye su procedencia en toda gestión independientemente de su naturaleza, a menos que sea excluida por el legislador, cuestión que no sería el caso de la acción declarativa para la constitución de un título ejecutivo (Rabat Celis, 2002, p. 117).

Cabe tener presente que en la gestión preparatoria de notificación de facturas, el recurso de apelación contra la resolución de la impugnación de factura se concede bajo el efecto devolutivo, de acuerdo a la Ley $\mathrm{N}^{\circ} 19.983$ (2004, art. 5, d). De esta forma, cabe preguntarse si comienza o no el cómputo del plazo exigido por el incidente, una vez que se deducen recursos -en ausencia de actividad de las partesconsiderando que tanto la apelación como la casación se conceden en el sólo efecto devolutivo. En otras palabras, ¿se vería obligado el emisor o cesionario de la factura a continuar la tramitación e iniciar el juicio ejecutivo incluso si el fallo favorable de primera instancia se encuentra impugnado ante la Corte de Apelaciones? Y lo mismo cabe preguntarse si el fallo de la Corte de Apelaciones se encuentra recurrido ante la Corte Suprema, en caso de haberse rechazado la impugnación.

Pareciera que lo más razonable sería considerar que no comienza a correr el cómputo del plazo del abandono del procedimiento existiendo recursos pendientes. Lo contrario puede llevar al absurdo de verse forzado el acreedor a comenzar la ejecución bajo condición de resolución.

En el sentido expuesto, se ha estimado que existe una cierta unidad en el proceso considerando sus distintas instancias empero los recursos que se deduzcan, por cuanto el incidente abarca ambas instancias del proceso, no afectando la concesión del recurso en su efecto devolutivo. En la misma sentencia citada, la Corte Suprema constató que:

...esta posibilidad concedida por la ley para que las partes puedan seguir actuando en el tribunal inferior cuando una apelación se concede únicamente en lo devolutivo, es facultativa y condicional. Facultativa, porque queda entregado a la voluntad de las partes instar o no por la prosecución del juicio puesto que los tribunales sólo actúan a requerimiento de parte interesada; y condicional, porque todo lo obrado ante el juez de primer grado queda entregado a lo que, en definitiva, resuelva el superior: si la resolución apelada es revocada, lo obrado con posterioridad quedará sin efecto y sin valor alguno. (Resolución N8114, 2016, cons. 11)

Cabe mencionar, eso sí, que, a diferencia de lo señalado recientemente, encontrándose recursos pendientes se ha declarado el abandono del procedimiento en 
primera instancia, lo que en nuestra opinión no parece razonable porque la inactividad del demandante no es atribuible a su negligencia, sino, que a la espera de obtener seguridad respecto del crédito que está cobrando.

Finalmente, si la gestión preparatoria de notificación de facturas es un juicio, que duda habrá, la notificación de la misma producirá la interrupción de la prescripción de conformidad al Código Civil (2000, art. 2518). Lo anterior, es sin perjuicio de la opinión de quienes sostienen que cualquier gestión preparatoria quedaría comprendido en el término "demanda judicial" del inciso tercero de dicho artículo 9.

\section{Las defensas del obligado al pago: impugnación de la factura}

La falta de caracterización de la naturaleza jurídica de la gestión preparatoria de notificación de facturas, creemos, ha dado pie a las diferentes soluciones judiciales respecto a las defensas que puede hacer valer el obligado al pago. Lo cierto es que los tribunales han divergido respecto a la procedencia de la impugnación de la factura por la falta de entrega de la mercadería o prestación del servicio; y si bien esta controversia podría estimarse superada al habérsele denegado esta defensa al deudor en la ley vigente, la correcta definición de esta diferencia nos permitirá comprender la pertinencia y eficacia de las medidas adoptadas por el legislador.

Como veremos, una vez definida la naturaleza jurídica de la factura y, como consecuencia, las excepciones que puede hacer valer el deudor durante su cobro, veremos que las modificaciones legislativas no parecen abordar el problema jurídico que se intentó comprender, y podría explicar las diferencias en las resoluciones judiciales.

\subsection{Defensas del deudor en la Ley de facturas (Ley $N^{\circ} 19.983,2004$ )}

Actualmente, y tras la reforma de la Ley № 20.956 (2016), la Ley Nº 19.983 (2004), establece como requisito para que la copia tenga mérito ejecutivo,

Que, puesta en conocimiento del obligado a su pago mediante notificación judicial, aquél no alegare en el mismo acto, o dentro de tercero día, la falsificación material de la factura o guía o guías de despacho respectivas, o del recibo a que se refiere el literal precedente, o que, efectuada dicha alegación, ella fuera rechazada por resolución judicial. (Ley $\mathrm{N}^{\circ} 19.983$, 2004 , art. 5, d)

A su turno, el artículo $3^{\circ}$ señala respecto a las defensas procesales que se pueden deducir contra el cesionario que

Serán inoponibles a los cesionarios de una factura irrevocablemente aceptada, las excepciones personales que hubieren podido oponerse a los cedentes de la misma, así como aquellas fundadas en la falta total o 
parcial de entrega de las mercaderías o de la prestación del servicio, sin perjuicio de las acciones civiles y penales que correspondan contra el emisor. (Ley $N^{\circ} 19.983,2004$, art. 3, no. 2)

Con lo anterior, se decidió - para proteger al cesionario de una factura- que el obligado al pago sólo podría alegar la falsificación de la misma, y no hacer valer excepciones personales que tenía contra el cedente, ni otras excepciones fundadas en la falta de entrega de las mercaderías o prestación del servicio. Con ello, aparentemente, se solucionaba una discusión permanente desde la dictación de la ley referida a la legitimación del deudor para deducir excepciones fundadas en la naturaleza jurídica del título, estas son, aquellas distintas a las "excepciones personales" a que hace referencia la ley.

Ahora bien, el texto original de la Ley $N^{\circ} 19.983$ (2004) -el proyecto original de la dicha ley, contemplaba como única causal de impugnación "...la falsificación material de la factura o guía o guías de despacho respectivas, o del recibo a que se refiere la letra b) del artículo precedente..." (Historia de la Ley $N^{\circ} 19.983,2018$, art. 5, c). Durante su tramitación, dicha disposición fue objeto de indicaciones en la respectiva comisión del Senado, donde se agregó la posibilidad de impugnar la factura por no haberse entregado la mercadería o prestado el servicio a que se refiere-, en su artículo $5^{\circ}$ letra d), otorgaba al obligado al pago la facultad para oponerse a la gestión del acreedor mediante las defensas de: (i) la falsificación material de la factura o guías de despacho respectivas; y (ii) la falta de entrega de la mercadería o de la prestación del servicio, establecía la disposición mencionada que la copia de la factura tendrá mérito ejecutivo para su cobro, si cumplía con los siguientes requisititos:

d) Que, puesta en conocimiento del obligado a su pago mediante notificación judicial, aquél no alegare en el mismo acto, o dentro de tercero día, la falsificación material de la factura o guía o guías de despacho respectivas, o del recibo a que se refiere el literal precedente, o la falta de entrega de la mercadería o de la prestación del servicio, según el caso, o que, efectuada dicha alegación, ella fuera rechazada por resolución judicial. La impugnación se tramitará como incidente y, en contra de la resolución que la deniegue, procederá el recurso de apelación en el solo efecto devolutivo. (Historia de la Ley $N^{\circ} 19.983,2018$, pp. 123, 139, 143, 146$147,150,154)$

Luego, la Ley № 20.323 (2009) limitó aún más las excepciones que se podían deducir contra el cesionario, al agregar que "Serán inoponibles a los cesionarios de una factura irrevocablemente aceptada, las excepciones personales que hubieren podido oponerse a los cedentes de la misma" (art. Único, no. 1).

Con lo anterior, se vislumbra la intención del legislador de ir reduciendo el catálogo de defensas a que podía echar mano el deudor, primero, limitando la procedencia de las "excepciones personales", y luego, eliminado la posibilidad de impugnar la factura, en razón de la falta de mercadería o servicio. 
Ahora bien, para evaluar la pertinencia sobre la limitación de las excepciones, el legislador debió cuestionarse qué excepciones podían deducirse naturalmente contra el adquirente de una factura; y para ello, debió analizar, previamente, la naturaleza jurídica del título. Al no haberse realizado ello, según se demostrará, llevó al legislador a dictar modificaciones que generaron más problemas que soluciones.

\subsection{La factura como título causado}

\subsubsection{La factura según la Ley $N^{\circ} 19.983$}

La Ley Nº 19.983 (2004) no establece qué naturaleza jurídica detenta la factura, siendo la doctrina y la jurisprudencia -para un análisis de la evolución jurisprudencial, véase Escobar Saavedra y Hoyuela Zattera (2016, p. 13)- quienes se han encargado de entregar una aproximación. Al respecto, es bastante compartida la opinión según la cual esta ley se creó un título de circulación causado, -sin perjuicio que haya autores que incluso le nieguen la naturaleza de título de crédito (Escobar Saavedra y Hoyuela Zattera, 2016, p. 12)-, al respecto, título de crédito es "un documento transferible cuya posesión es necesaria para ejercer el derecho literal y autónomo que en él se representa" (César Vivante, citada por Sandoval López, 2007, pp. 11-12), en un sentido similar, "título de crédito, efecto de comercio o documento negociable, es el documento que confiere a su tener legal el derecho de obtener a su vencimiento la solución o pago de la obligación estipulada" (Palma Rogers, 1940, p. 384).

Son títulos causados aquellos representativos de mercaderías o títulos de tradición, toda vez que no se abstraen de la relación fundamental o subyacentes al título, condicionando la exigibilidad del derecho personal que ellos materializan (Escobar Saavedra y Hoyuela Zattera, 2016, p. 10); y ello permite ejercitar el derecho que contienen, tal como ocurre con la carta de porte, el conocimiento de embarque, el certificado warrant y la factura, en cuanto esta última se refiere a una compraventa, prestación de servicios u otras operaciones semejantes (artículo $1^{\circ}$ ) (Sandoval López, 2007, pp. 48-49).

Así lo ha dicho, por ejemplo, Prado Puga (2016), al señalar que

...tanto el vendedor como el prestador de un servicio o sus cesionarios posteriores a la emisión de la factura, están en condiciones de conocer a cabalidad la situación del crédito contenido en la factura, sea para cobrarlo, pagarlo, o bien, para cederlo nuevamente a un tercero. (p. 164)

Y al analizar los requisitos y formalidades de la cesión, especifica que la factura -a diferencia de los "títulos abstractos" como son el pagaré o la letra de cambio- no comparte la literalidad que sí tienen tales títulos de crédito, toda vez que ésta en su circulación constata las mercaderías vendidas o arrendadas, o dando cuenta de los servicios prestados, individualizándolos (Prado Puga, 2016, p. 166). En el mismo sentido, se ha dicho que la factura no tendría el carácter de "literalidad" que tienen el 
pagaré o la letra de cambio; el espíritu del legislador sólo fue regular su transferencia y otorgarle mérito ejecutivo a una copia de ella (Román Rodríguez et al., p. 15).

Además, para que la factura pueda circular requiere de la conformidad del deudor, esto es, su aceptación irrevocable del contenido de la misma, lo que cumple la función de crear la obligación intrínseca, adquiriendo así su naturaleza de efecto de comercio, según enseña Rioseco Enríquez (2005, p. 133). Como consecuencia de la aceptación y constancia de recibo de las mercaderías o servicios, las excepciones personales del deudor le resultan inoponibles al acreedor Rioseco Enríquez (2005, p. 139).

Por lo anterior, la factura viene a ser un título valor autónomo, independiente del negocio causal, pero no abstracto o desvinculado del mismo, como lo son, la letra de cambio, el pagaré y el cheque. En palabras de Sandoval López (2015):

...la denominación título de crédito se reserva en la actualidad para los documentos que contienen una prestación consistente en el pago de una suma de dinero, como la letra de cambio, el pagaré y el cheque. Existe una relación de género a especie entre título-valor y título de crédito. ( $p$. 34).

El mismo autor explica,

...el carácter autónomo de un título de crédito se explica porque el titular del mismo lo adquiere en forma originaria, es decir, su derecho no deriva del tradente, sino que nace nuevo en el adquirente al recibir el documento según su ley de circulación. (Sandoval López, 2015, pp. 41-42)

$Y$, en consecuencia el demandado puede oponer excepciones reales fundadas en el documento mismo, pero no en las anteriores relaciones personales de sus tenedores.

Esta caracterización ha sido reconocida por nuestra Corte Suprema. A modo ejemplar, por sentencia del año 2016, el máximo tribunal resolvió que

...la factura, atendido el claro tenor de las normas de la Ley $\mathrm{N}^{\circ} 19.983$, especialmente de los artículos $1^{\circ}$ y $4^{\circ}$ letras a) y b), no ha resultado ser un título abstracto, independiente de la relación causal que le dio origen, como ocurre con la letra de cambio y el pagaré, sino que constituye un título causado, ligado al negocio del que ha nacido. (Resolución $\mathrm{N}^{\circ} 40604$, 2016, cons. 10; en el mismo sentido, Resolución № 552845, 2016, cons. 11)

Especificando igualmente que:

Dista así la factura de la abstracción cambiaria que le es inherente a los efectos de comercio, como son la letra de cambio, el pagaré y el cheque, 
cuyos títulos de crédito son incausados, por cuanto no se contiene en ellos ninguna referencia a la relación jurídica que ha servido de base a su creación o transferencia y, de consiguiente, esa relación no podría tampoco afectar la validez del título, ni menos a la eficacia del derecho que se desprende del documento, nada de lo cual tiene aplicación respecto de la factura comercial ni asidero en las copias que se pretenden cobrar. (Resolución $\mathrm{N}^{\circ} 566372,2016$, cons. 9)

\subsubsection{Las modificaciones de la Ley $N^{\circ} 20.323$}

La Ley N²0.323, de 29 de enero de 2009, modificó la Ley № 19.983 (2004) con el objeto de facilitar la factorización de facturas por pequeños y medianos empresarios, agregando en el artículo $3^{\circ}$ una limitación para el caso en que el notificado impugnara la factura contra el cesionario de su copia. Así, la Ley Nº 19.983 (2004) reformada pasó a establecer que "Serán inoponibles a los cesionarios de una factura irrevocablemente aceptada, las excepciones personales que hubieren podido oponerse a los cedentes de la misma" (art. 3).

Contrariamente a lo que han sostenido los fallos que comprenden a la factura como un título abstracto, como veremos a continuación, estimamos que si bien en la historia de la Ley $N^{\circ} 20.323$ se vislumbra la idea originaria del legislador de otorgarle dicho carácter, ello no se cumplió y la factura no dejó de ser un título causado. Desde ya, hacemos el alcance que ha existido jurisprudencia en sentido diverso: en un voto de minoría de un fallo de la Corte Suprema se refirió al carácter abstracto de la factura en una lectura que no compartimos de la historia de la ley:

...es pertinente consignar que en la sesión 84 de la Comisión de Economía del Senado, de 16 de enero de 2008, al discutirse la indicación $\mathrm{N}^{\circ} 2$ que motivó la introducción del inciso final del artículo $3^{\circ}$ de la Ley $\mathrm{N}^{\circ}$ 19.983, el señor Orpis manifestó que "el objetivo de la Comisión, en torno al que habría consenso, apunta a independizar la factura del negocio causal", añadiendo el señor Rubio que "el Ejecutivo está de acuerdo en avanzar en esa línea, es decir, que una factura bien emitida puede transformarse en un título independiente", mientras que el señor Vásquez agregó por su parte que "el título, en este caso la factura, se transformaría en un título abstracto" (Interfactor S.A. con I. Municipalidad de Molina, 2016, voto minoría no. 2).

Y así también lo ha reconocido el Tribunal Constitucional, según consta del fallo citado.

Ahora bien, consta en la historia fidedigna de la ley comentada que la modificación del artículo tercero se gestó en la Comisión de Economía del Senado. Originalmente, la modificación que se proponía rezaba: 
Toda estipulación que limite, restrinja o prohíba la libre circulación de un crédito que conste en una factura se tendrá por no escrita, siéndole, además, inoponibles a los cesionarios de facturas, las prendas, embargos, prohibiciones de enajenar o cualquier otra medida cautelar o contrato que grave o afecte a la factura cedida, así como, también, las compensaciones legales o convencionales que pudieran haber sido válidamente aplicables respecto del dueño original y cedente de las facturas, cuando corresponda. Se exceptúan de lo anterior, las prendas que el adquirente haya conocido y expresamente aceptado, como asimismo aquellas garantías, embargos y prohibiciones que hayan sido notificados judicialmente al cesionario (Historia de la Ley $N^{\circ} 20.323,2018$, p. 45).

Posteriormente, la discusión se centró en la posibilidad de convertir a la factura en un título autónomo -en palabras de uno de los Senadores en la discusión en la sala, la Comisión de Economía tuvo como visión que la factura se transformara en un título autónomo, de libre circulación, y que pueda gozar de mérito ejecutivo (Historia de la Ley $\mathrm{N}^{\circ} 20.323,2018$, p. 75)-, restringiendo así la limitación de las excepciones del deudor a las excepciones personales (haciéndolas "inoponibles", en palabras del legislador), mediante indicación, se propuso agregar la expresión:

...'siéndole además, inoponibles a los cesionarios de facturas, las compensaciones legales o convencionales que pudieran haber sido válidamente aplicables respecto del dueño original y el cedente de aquéllas, cuando corresponda, como asimismo cualquier otra excepción fundada en relaciones personales con el cedente de la misma. Sólo serán oponibles al cesionario de una factura, las prendas que éste haya conocido y expresamente aceptado, como asimismo aquellas garantías, embargos o prohibiciones que hayan sido notificados judicialmente al cesionario' ${ }^{3}$. (Historia de la Ley $N^{\circ} 20.323,2018$, p. 63)

No obstante la confusión de algunos $\mathrm{H}$. Senadores entre los términos "autonomía" y "abstracción" del título -sobre lo que ya se volverá-, quedó constancia que sólo podrían oponerse contra la factura las excepciones que emanaran del título mismo, y así pasó el proyecto a la votación de la sala del Senado.

Que las excepciones personales sean "inoponibles" significa

...que la ley ha aplicado como efecto a la cesión de la factura irrevocablemente aceptada- la misma consecuencia derivada del principio de la autonomía del título, que consagró la ley $\mathrm{N}^{\circ} 18.092$, de 14 de Enero de 1982, sobre Letra de Cambio y Pagaré en el artículo 28 para el endoso, al disponer que 'la persona demandada en virtud de una letra de cambio no puede oponer al demandante excepciones fundadas en rela-

\footnotetext{
${ }^{3}$ Con ello, quedó constancia en la discusión la inquietud de algunos parlamentarios de independizar a la factura del negocio causa que, a juicio de otros, significaría transformarla en un título abstracto, no obstante que guardaría algún grado de relación causal (sic). Asimismo, sobresalió el entendimiento de limitar todas las excepciones personales, incluyendo -equivocadamente- la nulidad del título, pero dejando a salvo las excepciones que emanan del título mismo.
} 
ciones personales con anteriores portadores de la letra'. De ahí que las excepciones personales que tuviere el deudor cedido contra el cedente de la factura se purgan, extinguen y mueren, por la simple transferencia del título. (Gómez Balmaceda, 2015, pp. 15-16)

En el mismo sentido, Sandoval López (2007) afirma sobre la "autonomía" del título en nuestra legislación que se manifiesta en el artículo 28 de la ley $N^{\circ} 18.092$, por cuanto establece "...la persona demandada en virtud de una letra de cambio no puede oponer al demandante excepciones fundadas en relaciones personales con anteriores portadores de la letra" (p. 41). Conviene anotar que dicha redacción es bastante similar al artículo $3^{\circ}$ de la Ley $\mathrm{N}^{\circ} 19.983$ (2004) bajo la reforma de la Ley $\mathrm{N}^{\circ}$ 20.323 (2009); porque, una vez en circulación el cesionario adquiere un derecho originario, independiente y distinto al de sus antecesores, siendo improcedente indagar en la validez del mismo en atención a sus relaciones personales (Gómez Balmaceda, p. 2015, pp. 18-19).

De esta forma, y para ser precisos, el legislador no creo un título abstracto alterando la naturaleza jurídica de la factura, sino, que consagró su carácter autónomo. Este entendido lo comparten diversos fallos de la Corte Suprema, por ejemplo, al reconocer que la modificación de la Ley $N^{\circ} 20.323$ (2009) a la Ley $N^{\circ} 19.983$ (2004), mediante la agregación del inciso final del artículo $3^{\circ}$ que incluye la inamovilidad de excepciones personales, no alteró los presupuestos de ley para que la factura adquiera mérito ejecutivo ni hizo innecesaria su gestión preparatoria para conferirle tal mérito (Incofin S.A. con Servicio de Salud Valparaíso San Antonio, 2016, cons. 9. Al respecto, ya con anterioridad ciertos fallos aceptaban el conocimiento de las excepciones permitidas por la Ley N 19.983 (2004), reconociendo su carácter causado, Copia de factura con mérito ejecutivo para su cobro. Requisitos, 2010, cons. 3 y s.).

Adicionalmente, corroboraría lo anterior el que la Ley $N^{\circ} 19.983$ (2004) establezca supletoriamente la aplicación de las normas de cesión de créditos del Código Civil (2000) para los créditos que consten en las facturas. Para Escobar Saavedra y Hoyuela Zattera (2016, p. 30), si la intención del legislador hubiese sido dotar a la factura del carácter de abstracción, habría aplicado supletoriamente las normas de la Ley No 18.082, sobre Letra de Cambios y Pagarés, que regula los efectos de tales actos abstractos. Por todo lo anterior, bien es dable concluir ante diversos entendimientos en nuestros tribunales que razonan sobre la abstracción de la factura -citados algunos más arriba-, que más bien existió en la discusión legislativa una confusión entre los términos de "abstracción" y "autonomía" del título, característica esta última que se predica de la factura, y no así la primera. En definitiva, nuestra doctrina se inclina por considerarla como un título causado, dependiente del negocio causal que la origina.

Pues bien, considerar a la factura como un título causado permitirá indagar en el vínculo causal o relación subyacente que la originó y, por tanto, haría jurídicamen- 
te posible impugnar una factura en virtud de excepciones que se refieren al título mismo y no a la relación entre las partes, cuales son, las excepciones reales.

\subsection{Consecuencias de la autonomía de la factura: procedencia de las ex- cepciones reales}

Que por la modificación de la Ley Nº 19.983 (2004) se haya otorgado a la factura la cualidad de "autonomía" de que gozan los títulos de crédito, conlleva -siguiendo a Sandoval López $(2015$, p. 47) - a que por dicha cualidad existe una relación directa entre el portador y el deudor primitivo, sin importar las relaciones personales entre tenedores intermedios, a diferencia de la "abstracción", en que se prescinde objetivamente incluso del negocio que dio origen al título (Sandoval López, 2015, p. 47). En sentido similar, Escobar Saavedra y Hoyuela Zattera (2016) afirman que:

El alcance de un título abstracto implica que, a medida que éste vaya circulando podrá prescindir de la relación jurídica fundamental que dio lugar a su emisión, luego al legitimado activo no podrán oponérsele excepciones de tipo real fundadas en la relación jurídica fundamental (p. 25).

Luego, el obligado al pago puede oponer al cesionario de la factura una excepción real sin perjuicio del carácter autónomo del título; y ahí la importancia en determinar si la falta de entrega de la mercadería o prestación del servicio signifique atender o no a la existencia del negocio causal: esto es, si es una excepción real o personal. Ni la Ley $N^{\circ} 19.983$ (2004), ni su historia fidedigna dan pautas para definirlo (Vergara Bezanilla, 2013, p. 43); y de la doctrina revisada sólo se ha encontrado respuesta en Escobar Saavedra y Hoyuela Zattera (2016, p. 24).

Dicha clasificación es enseñada por los autores nacionales al estudiar las relaciones entre los distintos deudores y su acreedor en las obligaciones llamadas de solidaridad pasiva y a propósito de las excepciones que puede oponer el fiador al acreedor (entre otros, Alessandri Rodríguez, Somarriva Undurraga y Vodanovic Haklickah, 2001, p. 148; Abeliuk Manasevich, 2008, pp. 438-440). La doctrina ha distinguido entre las excepciones reales y personales: las excepciones reales o comunes resultan de la naturaleza de la obligación; se refieren a los vicios o defectos de su origen y al nacimiento o extinción de las mismas, como sería la falta o ilicitud del objeto o causa de la obligación; la existencia de un plazo o condición; etc. A su turno, las excepciones personales no se refieren a la obligación misma, sino que a una relación particular del deudor con el acreedor, por cuanto "...dependen del estado o calidad de la persona, o son el resultado de las determinadas condiciones en que se encontraban en el momento de contratar" (Claro Solar, 1979, p. 442), luego señala como ejemplo las causales de rescisión del contrato por la omisión de requisitos establecidos en consideración a la persona o por vicios del consentimiento; las modalidades de los actos establecidas en razón del deudor; los modos de extinguir la obligación en razón de las relaciones con el deudor; y ciertos privilegios concedidos al deudor 
(Claro Solar, 1979, p. 443). Alessandri Rodríguez et al. (2001), con respecto a las excepciones personales indican que:

...se refieren al compromiso particular del deudor y proceden de una circunstancia que ha nacido, puede decirse, únicamente en su persona y que produce, en efecto, en su persona solamente un medio de defensa para sostener, que la obligación no ha sido, a su respecto, válidamente formada en su origen, sea que ella se ha extinguido posteriormente: se llaman personales, in personam, personae cohaerentes. (p. 148)

Por ello, pueden oponerse únicamente respecto de la persona en que concurren (Alessandri Rodríguez et al, 2001, p. 148). Coherentemente, la Corte Suprema ha afirmado que dichas excepciones se fundamentan en las relaciones personales de los intervinientes del negocio causal (Logros Factoring Spa con Municipalidad de Antofagasta(e), 2017, cons. 9).

En materia comercial, el legislador reconoce esta clasificación en el Código de Comercio (1865) que, al tratar la cesión de créditos, dispone que:

El deudor a quien se notifique la cesión y que tenga que oponer excepciones que no resulten del título cedido [aquellas personales], deberá hacerlas presentes en el acto de la notificación, o dentro de tercero día a más tardar, so pena de que más adelante no serán admitidas.

Las excepciones que aparezcan a la vista del documento o que nazcan del contrato [las reales], podrán oponerse contra el cesionario en la misma forma que habrían podido oponerse contra el cedente (art. 163)

Sobre este punto, Puelma Accorsi (1984, pp. 21-22) enseña que el principio cambiario de inoponibilidad de excepciones implica que el demandado sólo puede oponer las excepciones reales y personales suyas, que comprenden, respectivamente, las que constan en el documento y todas las demás (en un sentido similar, Palma Rogers, 1940, p. 394).

Ahora bien, una primera cuestión suscitada tras la reforma de la Ley $N^{\circ} 20.323$ (2009) se refiere a la interpretación de la limitación legal del artículo $3^{\circ}$ citado, esto es, el sentido y alcance del término "excepción personal" como limitación del deudor de una factura en contra del cesionario, y que es uno de los principales temas controvertidos en los juicios de facturas: la falta de entrega de la mercadería o de prestación del servicio, ¿es una excepción real o personal?

Reiterada jurisprudencia ha negado a los "deudores" de una factura la posibilidad de excepcionarse frente a sus cesionarios por la falta de entrega de la mercadería o de prestación del servicio, al considerarlas -quizás tautológicamente- excepciones personales en virtud de una supuesta naturaleza abstracta del título (Tanner Servicios Financieros S.A. con Fisco de Chile (E), 2018, cons. 6. En el mismo sentido, Resolución N¹92780, 2014, cons. 8). Dicha argumentación, como vimos, es errada. 
Eso sí, una de las razones más explicativas para justificar que la falta de prestación de servicios sería una excepción personal, según los fallos revisados de la Corte Suprema, sería que los fundamentos de ella "... dan cuenta de la relación contractual que ligó a la demandada y al cedente..." (Logros Factoring Spa con Municipalidad de Antofagasta(e), 2017, cons. 10), cuestión que haría referencia a una "...vinculación directa y particular, nacida a propósito del contrato de prestación de servicios celebrado..." (Logros Factoring Spa con Municipalidad de Antofagasta(e), 2017, cons. 10). A juicio de la Corte Suprema, ello demostraría que la excepción se origina en virtud del vínculo personal que tuvo el deudor con el acreedor original,

...cuya exigibilidad en lo que respecta a las obligaciones recíprocas, y dentro de ellas la prestación del servicio, dependerá única y exclusivamente del modo particular en que se haya desplegado la relación contractual entre las partes.

Así las cosas, el entorno que dio origen a la relación entre el cedente y el deudor aparece como ajeno al cesionario de la factura, en la medida que el incumplimiento específico que se reclama en cuanto a la falta de prestación del servicio viene a constituir una situación que involucra única y exclusivamente a aquellos sujetos que participaron en la primitiva relación contractual, y que por lo mismo no empece al cesionario demandante de autos, por lo que a su respecto, no le son oponibles. (Logros Factoring Spa con Municipalidad de Antofagasta(e), 2017, cons. 10).

No obstante lo anterior, existen razones para considerar que la falta de entrega de la mercadería o de la prestación del servicio debe considerarse como una excepción "real" en cuanto ella se plantea haciendo referencia a la relación subyacente al título. Y así se ha fallado:

En todo caso, las excepciones personales a que se refiere el inciso final del artículo $3^{\circ}$ de la ley antes mencionada, corresponden a aquéllas que sólo pueden oponerse respecto de determinadas personas como ocurre con la nulidad relativa, la compensación, la condonación de la deuda total o parcial, etc. Así, no resulta posible entonces, contar entre tales excepciones personales las ligadas al negocio causal o convención, cuya es la situación, por ejemplo, de la excepción de contrato no cumplido, nulidad de la obligación, prescripción, u otra que tenga estrecha relación con la obligación misma. En este contexto, cabe concluir que, en todo caso, tampoco la impugnación de la gestión previa relacionada con la 'falta de prestación del servicio', resulta asimilable a una excepción propiamente de carácter personal, en los términos que lo establece el artículo $3^{\circ}$ de la ley antes citada. (Incofin S.A. con Servicio de Salud Valparaíso San Antonio, 2016, cons. 10)

Como enseña Rioseco Enríquez (2005, p. 124), es menester que exista un contrato de compraventa o de prestación de servicios en el que se adquieran o presten unos $u$ otros para que la factura produzca efectos legales, por cuanto su destinatario 
estará sujeto a una obligación de dar al vencimiento del crédito de que da cuenta el título. Así, si en incumplimiento de las normas que rigen la factura, el título no hace mención al objeto, la cosa vendida o el servicio prestado, o si fuese ilícito, el título estaría viciado de nulidad (Rioseco Enríquez, 2005, p. 132). Luego, y con mayor razón, la factura estará igualmente viciada si el objeto no existe o "falta".

Además, si bien con la Ley Nº 19.983 (2004), el documento puede constatar la existencia de un crédito mediante la incorporación de un derecho obligacional al instrumento material -de carácter vinculante, incondicional e irrevocable como corresponde a todo título de crédito o efecto de comercio (Rioseco Enríquez, 2005, p. 125)-, históricamente, la factura del artículo 160 del Código de Comercio (1865) fue concebida como uno de los títulos representativos de mercaderías (Palma Rogers, 1940, pp. 386; Rioseco Enríquez, 2005, p. 125; Sandoval López, 2007, p. 10, reconoce como título representativo de mercaderías la Carta de Porte del Código de Comercio, al respecto, Gómez Balmaceda, 2015, p. 7, en su estudio sobre facturas comerciales, reconoce a la carta de porte del Código de Comercio como un antecedente relativo a la historia fidedigna de la dictación de la Ley $\left.N^{\circ} 19.983\right)$, cuales son los que su tenencia no da cuenta de la obligación de pagar una suma de dinero, sino que, de posesión de las especies obligando al deudor a su entrega en los términos señalados en el instrumento (Rioseco Enríquez, 2005, pp. 124-125). De esta forma, como título representativo de mercaderías -que bajo la legislación actual provendrían de una compraventa, prestación de servicios o aquellas operaciones que se les asimilen (Valencia Arancibia, 2004, p. 17; Rioseco Enríquez, 2005, p. 125)-, la factura haría referencia a la relación subyacente, por lo que alegar la falta de ellas equivaldría a denunciar la falta de objeto de la relación causal.

Desde la perspectiva del deudor, es interesante citar el voto de disidencia de un fallo de la Corte Suprema que argumentó que, en atención al carácter causado de la factura, la obligación de pago a que está compelido debe tener una causa de conformidad al Código Civil (2000, arts. 1445 y 1467), salvo que exista norma expresa que establezca el carácter abstracto del crédito. Así, respecto del crédito que consta en la factura, señala la disidencia,

...la causa que da derecho del acreedor para cobrarlo es el hecho de que efectivamente se haya vendido y entregado determinadas mercaderías o prestado efectivamente ciertos servicios. Tanto así que la misma ley exige al momento de cederse la copia de la factura emitida que en ella conste la recepción de las mercaderías o la prestación de los servicios, de la manera y con las indicaciones que prescriben en la letra b) del artículo $4^{\circ}$ de la Ley 19.983 (Resolución № 214494, 2014, cons. 20, no. 5).

Por lo anterior, se concluye que la reclamación de que la mercadería no fue entregada o el servicio prestado sería, precisamente, alegar que la obligación no tiene una causa para su cobro, cuestión inherente al crédito que se demanda. Con ra- 
zón, concluye su autor tajantemente que una interpretación contraria sería convertir a la factura en un título incausado o abstracto, que como vimos, no lo es.

Este criterio fue sostenido recientemente por un fallo de la Corte Suprema, que declaró en un juicio ordinario la nulidad de un pago efectuado al cesionario de una factura, en razón de servicios inexistentes. En palabras del máximo tribunal, la convención de pago, al no corresponder a servicios que fueron realmente prestados por la emisora de las facturas, carece de causa (Ferretería el Águila Limitada con Logitranss Spa (O), 2018, cons. 5). La Corte Suprema concluyó que, en atención a la falta de causa de un doble pago en razón de un contrato de transporte,

...la sentencia recurrida, al rechazar la demanda de la actora recurrente por estimar erróneamente inoponibles a la demandada Factotal S.A., cesionaria de las facturas, las alegaciones de la demandante y su pretensión de nulidad absoluta de la convención de pago fundadas en la inexistencia parcial del servicio de transporte, por haber incurrido en la duplicidad de facturación reconocida por el propio sentenciador, ha infringido también la norma del artículo $3^{\circ}$ de la Ley $\mathrm{N}^{\circ} 19.983$ invocada en el recurso de casación sustancial, al entenderla aplicable en la especie no obstante tratarse de una situación absolutamente diversa, en la cual resulta necesariamente pertinente la norma general del también citado artículo 163 inciso $2^{\circ}$ del Código de Comercio. (Ferretería el Águila Limitada con Logitranss Spa (O), 2018, cons. 11)

Por último, la gestión preparatoria tiene por objeto la notificación de la factura al deudor para otorgarle mérito ejecutivo al título. Luego, el objeto del procedimiento es el título mismo y la obligación contenida en él, por lo que es dable concluir que la impugnación del deudor se refiere a la existencia o validez del título, con el objeto de negarle el carácter ejecutivo por su inexistencia o invalidez, y no por una relación personal con el acreedor.

Finalmente, conviene tener presente que, en un sentido diverso al que se ha comentado hasta ahora, se ha fallado que la distinción entre excepción real y personal no es propia de la gestión preparatoria de notificación judicial, sino, del juicio ejecutivo. En este sentido, en un voto de minoría de un fallo de la Corte Suprema, se constató que:

Que el sistema de impugnación incidental previsto por el artículo 5 letra d) de la ley antes referida, está contemplado, a propósito de los requisitos descritos para dotar a la factura de fuerza ejecutiva -y específicamente en lo que interesa, se lo ha concebido en la gestión previa de notificación de la factura-, por lo que resulta ineludible este último trámite para cualquiera que pretenda el cobro ejecutivo, sin que sea posible asimilar esta impugnación con las excepciones que el procedimiento de ejecución proporciona al demandado. En consecuencia, es en esta última sede que cobrará interés el distinguir entre excepciones reales y personales y/o mixtas y no en la presente gestión preparatoria de la vía ejecutiva. (Reso- 
lución N 192780, 2014, cons. 14, II, no. 3; en el mismo sentido, Resolución $\mathrm{N}^{\circ}$ 552845, 2016, cons. $10 \mathrm{y}$; Incofin S.A. con Servicio de Salud Valparaíso San Antonio, 2016, cons. 9)

Con ello, la limitación a las excepciones personales aplicaría únicamente en dicha etapa: no compartimos dicho entendimiento, en razón de lo explicado en el primer capítulo. Esta solución, además, es contradictoria con un fallo de la Corte Suprema por el cual sostuvo que la desvinculación del negocio causal se produciría una vez que se ha concluido la gestión preparatoria de notificación de facturas, denegando al obligado la excepción de falta de prestación de los servicios sólo en la etapa ejecutiva:

Que, por tanto, no es posible en esta etapa procesal, cuando la factura ya se ha desvinculado de su negocio causal, alegar la falta de prestación del servicio por la vía de la excepción del artículo $464 \mathrm{~N}^{\circ} 7$ del Código de Procedimiento Civil, toda vez que se trata de una alegación que resulta propia de la etapa preparatoria y no puede oponerse en esta oportunidad, cuando ya se ha tenido por preparada la vía ejecutiva por resolución ejecutoriada. (Resolución N 150127, 2016, cons. 11)

No vislumbramos razones para entender este razonamiento. Si bien explica la procedencia de excepciones en la gestión preparatoria, aceptarla lleva a la hipótesis que el deudor no podría echar mano -según la legislación actual- a ninguna excepción, ni real ni personal, en ambas sedes.

\subsection{Situación tras la reforma de la Ley $\mathbf{N}^{\circ} \mathbf{2 0 . 9 5 6}$}

La Ley N² 20.956 (2016), como hemos venido diciendo, restringió la procedencia de las excepciones que podía hacer valer el deudor, eliminando la posibilidad de deducir las excepciones reales durante la gestión preparatoria. Esta ley modificó parcialmente a la Ley № 19.983 (2004, art. 5, d), en la parte que hacía mención a la impugnación de la factura por falta de la entrega de la mercadería o de la prestación del servicio, al establecer como requisito para que la copia tenga mérito ejecutivo,

Que, puesta en conocimiento del obligado a su pago mediante notificación judicial, aquél no alegare en el mismo acto, o dentro de tercero día, la falsificación material de la factura o guía o guías de despacho respectivas, o del recibo a que se refiere el literal precedente, o que, efectuada dicha alegación, ella fuera rechazada por resolución judicial. (Ley $\mathrm{N}^{\circ} 19.983$, 2004 , art. 5, d)

A su turno, modificó el artículo $3^{\circ}$, limitando las excepciones que se pueden deducir contra el cesionario, señalando que

Serán inoponibles a los cesionarios de una factura irrevocablemente aceptada, las excepciones personales que hubieren podido oponerse a los cedentes de la misma, así como aquellas fundadas en la falta total o 
parcial de entrega de las mercaderías o de la prestación del servicio, sin perjuicio de las acciones civiles y penales que correspondan contra el emisor. (Ley $N^{\circ} 19.983,2004$, art. 3, no. 2)

Cabe agregar que la Corte Suprema declaró la imposibilidad de aplicar retroactivamente la limitación contemplada en la ley actual conforme al artículo 24, de la Ley sobre Efecto Retroactivo de las Leyes (1861), porque:

...esta excepción es puramente procesal, sin que sea jurídicamente aceptable imputar a la posibilidad de alegar una determinada defensa, en este caso, la falta de prestación de servicios, la condición de ley procedimental, porque manifiestamente se trata de una norma sustantiva, lo que impide hacer operativa la aludida excepción. (Banco Itaú Chile con Comando de Bienestar del Ejército (E), 2017, cons. 5; Este criterio se ha mantenido, Banco de Chile con Tecnasic S.A., 2017)

La agregación indicada en el párrafo anterior tiene su origen en una indicación al proyecto de ley por parte del Ejecutivo, que propuso adicionar como limitación, la frase "así como aquéllas fundadas en la falta total o parcial de entrega de las mercaderías o de la prestación del servicio, sin perjuicio de las acciones civiles y penales que correspondan contra el emisor" (Historia de la Ley $N^{\circ} 20.956,2021$, p. 221) ${ }^{4}$. A propósito de la indicación $3^{a}$ del Ejecutivo, se dejó constancia de que se buscaba

...dar certeza acerca de la irrevocabilidad de la aceptación, haciendo, además, inoponible respecto de terceros excepciones personales o fundadas en la falta de entrega de los bienes o de la prestación de los servicios, dejando siempre a salvo los casos en que exista una responsabilidad civil o penal del emisor. Por lo mismo, agregó, más adelante se elimina la presunción de derecho de la entrega de los bienes o la prestación de los servicios, dejándola como simplemente legal. (Historia de la Ley $\mathrm{N}^{\circ}$ 20.956, 2021, p. 229)

Dicha indicación fue aprobada unánimemente por la comisión correspondiente y luego por la sala del Senado sin mayor análisis. Con lo anterior, volvió a la Cámara de Diputados agregándose las expresiones que

'La factura también se tendrá por irrevocablemente aceptada cuando el deudor, dentro del plazo de ocho días señalado anteriormente, declare expresamente aceptarla, no pudiendo con posterioridad reclamar en contra de su contenido o de la falta total o parcial de entrega de las mercaderías o de la prestación del servicio'.

...', así como aquéllas fundadas en la falta total o parcial de entrega de las mercaderías o de la prestación del servicio, sin perjuicio de las acciones civiles y penales que correspondan contra el emisor'. (Historia de la Ley $\mathrm{N}^{\circ}$ 20.956, 2021, p. 280)

\footnotetext{
${ }^{4}$ Boletín de Indicaciones del Ejecutivo y Parlamentarios. 11 de agosto de 2016. Indicación N 3.
} 
Ahora bien, el proyecto original contenía una presunción de derecho de haberse entregado las mercaderías o prestados los servicios

En caso que el recibo no haya sido efectuado en el plazo señalado y tampoco haya existido reclamo en contra de su contenido o de la falta total o parcial de entrega de las mercaderías o de la prestación del servicio mediante alguno de los procedimientos establecidos en el artículo $3^{\circ} \ldots$ (Historia de la Ley $\mathrm{N}^{\circ} 20.956,2021$, p. 14)

Más tarde, el Ejecutivo propuso que la presunción fuera simplemente legal (Historia de la Ley $N^{\circ} 20.956,2021$, p. 229), por cuanto se extendía respecto de los cesionarios de una factura tanto la inoponibilidad de las excepciones personales como aquellas fundadas en la falta de objeto de la prestación, quedando a salvo las acciones civiles o penales contra el emisor, y así, el cesionario suficientemente protegido. Dichas modificaciones merecen los siguientes comentarios.

En primer lugar, la redacción

Serán inoponibles a los cesionarios de una factura irrevocablemente aceptada, las excepciones personales que hubieren podido oponerse a los cedentes de la misma, así como aquellas fundadas en la falta total o parcial de entrega de las mercaderías o de la prestación del servicio....(Ley $\mathrm{N}^{\circ} 19.983,2004$, art. 3)

Ha vuelto a traer en discusión la naturaleza jurídica de la falta de entrega de las mercaderías o prestación del servicio. En efecto, el tenor meramente ejemplar de la expresión "así como" ha causado que cierta jurisprudencia insista en que estas defensas son excepciones personales, incluso para la resolución de casos iniciados con anterioridad a la vigencia de la ley actual, la Corte Suprema resolvió:

Que la inoponibilidad al cesionario de las excepciones personales, como lo es en este caso la falta de prestación del servicio, ha sido reconocida por la jurisprudencia de la Corte Suprema en la causa rol 8496-15 y recientemente en la sentencia rol 18.125-17. Este razonamiento ha sido reforzado por la Ley N 20.956, que si bien por su fecha de vigencia no resulta aplicable al caso en examen, recoge la interpretación que esta Corte ven a haciendo del artículo 3 de Ley № 19.983. (Factoring Andino Servicios Financieros S.A. con Import. Export. Stop S.A., 2017, cons. 3)

En segundo lugar, observamos que la limitación de las excepciones reales señaladas en la Ley $N^{\circ} 20.950$ (2016) obedece antes a un criterio "económico" por parte del legislador que a una modificación sustantiva de la naturaleza jurídica de la factura, a través de una reducción del catálogo de excepciones del deudor. Ahora bien, como concluimos en el primer capítulo, de forma contraproducente la limitación para la impugnación de la factura no impide al deudor para excepcionarse del pago en sede ejecutiva invocando alguna de las excepciones de la Ley $N^{\circ} 1.552$ 
(1902, art. 464). En nuestro concepto, la modificación solo logrará la postergación de la discusión sobre el objeto de la factura para la sede ejecutiva, dilatando así la incertidumbre del adquirente de la misma.

En efecto, fallos recientes de la Corte Suprema han reconocido la posibilidad de deducir en sede ejecutiva las excepciones fundadas en la relación subyacente del título, a través del amplísimo catálogo del artículo 464 (particularmente, las de los numerales 6, 7 y 14). Así, por ejemplo:

Con la modificación incorporada por la Ley 20.956, al retirar de la oposición a la gestión preparatoria de la vía ejecutiva a la excepción de "la falta de prestación del servicio o la falta de entrega de la mercadería" (antiguo art. $5^{\circ}$ letra d), para trasladarla como argumento para evitar la aceptación inrrevocable de la factura (actual art. $3^{\circ}$ ), ello no impide que en el futuro, en sede ejecutiva, el obligado al pago se oponga a la ejecución fundado el artículo 464 del Código de Procedimiento Civil. En otras palabras, si bien esta defensa no tendrá lugar en el capítulo de oposición a la gestión preparatoria de la vía ejecutiva por más que la factura esté irrevocablemente aceptada aquello no obsta a que el ejecutado pueda, dentro del contradictorio que supone el juicio ejecutivo, oponer las excepciones a que se refiere el señalado artículo 464. (Morbiducci Ingeniería en Geomensura Limitada con Saldaño Martínez David Kendal.(E), 2020, cons 7)

Asimismo:

3. Que, en otras palabras, la particular naturaleza de la factura determina que nunca será un título incausado. Antes bien, se mantiene vinculada al negocio que origina su expedición y a sus efectos ya que, no obstante haber sido cedida, el deudor bien puede oponer al cesionario excepciones reales que dicen relación precisamente con la obligación emanada de ese negocio causal.

4. La modificación que la Ley $N^{\circ} 20.956$ introdujo a la Ley $N^{\circ} 19.983$ en orden a que el deudor no puede oponer al cesionario de una factura irrevocablemente aceptada excepciones personales que hubiera podido oponer al cedente de la factura, ni aquellas fundadas en la falta total o parcial de entrega de las mercaderías o de la prestación del servicio, sólo significa que no puede defenderse arguyendo aquellas que sólo ha valido oponer ante el cedente, pero no le está vedado oponer al cedente, por ejemplo, la inexistencia o inoponibilidad de la obligación. (Finameris Servicios Financieros S.A. con Gestión Vial Limitada (E), 2020, cons. 3 y 4; en el mismo sentido, Rebolledo/Figuz S.A., 2020, cons. $3^{\circ}$ )

En tercer lugar, si bien la Ley № 20.950 (2016) limitó las defensas del obligado al pago en contra del emisor y en contra del cesionario de una factura durante la gestión preparatoria, la modificación dejó a salvo las acciones civiles o penales contra el emisor. Dicha disposición puede tener dos explicaciones: (i) que, sin perjuicio de la presunción, el deudor igualmente podrá acreditar la falsedad de entrega de las mer- 
caderías o prestación de los servicios al ejercer acciones civiles o penales contra el emisor, pero estará obligado frente al cesionario de esa factura; o bien, (ii) que será el adquirente de una factura el que podrá dirigirse contra el emisor, en caso de falta de pago por parte del deudor al rechazarse en juicio el cobro de la factura, por la falta de contraprestación. Empero, es dable concluir que la primera alternativa es más concordante con la lógica de proteger al cesionario de una factura y la limitación de las excepciones del deudor, como es la imposibilidad de alegar la falta de entrega de la mercadería o prestación del servicio.

Finalmente, cabe resaltar que estas consideraciones no se ven afectadas por las modificaciones introducidas por la Ley $N^{\circ} 21.131$ (2019), que establece pago a treinta días. Ello, en cuanto el objeto de la ley -como lo dice su nombre- fue la regulación del pago del saldo insoluto de la factura de manera efectiva en un plazo máximo de treinta días, con las salvedades que se establecen en el texto. La reforma recae sobre artículos distintos al $3^{\circ}$ y $5^{\circ}$, que contienen en gran parte la materia de este estudio, a excepción de una modificación menor referida a la aceptación de la factura.

\section{Carga de la prueba de la impugnación}

Como dijimos, en la actual Ley $\mathrm{N}^{\circ} 19.983$ (2004), tras la modificación de la Ley $\mathrm{N}^{\circ}$ 20.956 (2016), el cesionario del título goza, tras cumplirse el plazo del numeral segundo del artículo $3^{\circ}$, de una presunción de entrega de la mercadería o de la prestación del servicio contenido en la factura, los que además no pueden ser objetados por el obligado al pago durante la gestión preparatoria.

No ocurría lo mismo respecto del obligado con anterioridad a la vigencia de la Ley N² 20.956 (2016), quien sí podía impugnar la factura en virtud de las causales comentadas, y no tenía en su contra la presunción mencionada, por lo que surgía la duda sobre quién debía acreditar o destruir los hechos en que se funda la impugnación.

Sobre este punto, nuevamente, la jurisprudencia ha sido contradictoria. Por una parte, se ha sostenido que es el deudor quien debe probar la falta de entrega de las mercaderías o de prestación del servicio, fundado básicamente en que la cesión ha cumplido con los requisitos del artículo $3^{\circ}$; en este entendido, la Corte de Apelaciones de Santiago resolvió que:

...es precisamente el que alega la falta de prestación de los servicios el que debe establecer tal aserto, puesto que en el caso de la especie, la factura fue factorizada y se cobra judicialmente por un tercero, quien ha dejado constancia que cumplió con los trámites que establece el artículo $3^{\circ}$ de la Ley № 19.983 [...] 
Por esta razón, no es el cesionario e impulsor de la gestión preparatoria quien debe probar la prestación de los servicios, sino que es quien alega dicha excepción el que ha de establecerla. (Resolución N598646, 2015, cons. 6)

En otro fallo, la misma Corte de Apelaciones sostuvo que con este criterio

...no es que se imponga al incidentista la carga de probar un hecho negativo, sino que sosteniendo un hecho contrario al que se presume del documento que la ley entiende irrevocablemente aceptado, le corresponde la prueba de los supuestos fácticos que desvanecerían la presunción... (CBP Financia Capital Factoring S.A. / LG Electronics Inc. Chile Limitada, 2018, cons. 5)

$Y$, por la otra, que es el cesionario quien debe probar los hechos que justifican el cobro, en razón de no contar con un título ejecutivo que contenga una presunción de verdad sobre la existencia de la obligación, rigiendo al respecto la norma general del artículo 1698 del Código Civil (Contemporánea Factoring S.A. con Aserraderos Arauco S.A, 2011, cons. 21 y 22).

Creemos que para dilucidar lo anterior se debe considerar, primero, que el acreedor cuenta con un título que se entiende que el deudor ha aceptado "irrevocablemente" -no obstante estar a salvo su derecho de impugnar el contenido-. En otras palabras, si bien el deudor aún puede oponerse al cobro por no haberse cumplido con la entrega o prestación contenida en el documento, el acreedor goza de una suerte de presunción de haberse efectuado, toda vez que el deudor la ha aceptado. Luego, será el obligado al pago quien en caso de oposición deba acreditar, en primer término, que la aceptación no ha sido realmente dada para negarse a la ejecución y desvirtuar la aceptación que aparece en la factura, la propuesta es coherente con lo que enseña Sandoval López (2007) como característica de los títulosvalores, que valga citar:

3. La relación entre quienes están vinculados por el negocio subyacente y quienes no lo están, tiene distinta relevancia jurídico-doctrinaria. La situación entre el emisor y el beneficiario directo no ofrece duda porque están ligados por la relación fundamental. No ocurre lo mismo con los terceros portadores del documento. Para la legislación cambiaria el portador legitimado es un tercero de buena fe, que no participó en el negocio o relación fundamental, y como su voluntad no se tuvo en cuenta al convenirse dicha relación, es ajustado a derecho que las consecuencias jurídicas de tal negocio no le sean oponible.

4. Al ser así no se lesionan el rigor cambiario ni el favor de la circulación, porque el sistema cambiario presume la existencia de la causa del título, dando la posibilidad al sujeto pasivo de la relación fundamental de enervar la relación cambiaria. En tal caso, la forma de hacerlo es acreditar la inexistencia, la ineficacia o el carácter viciado de la relación subyacente. 
Sólo que se invierte el peso de la prueba, porque éste recae en el sujeto que se defiende o se excepciona. (p. 42)

Lo anterior, para el caso en que dicha negativa esté reforzada de un hecho positivo, distinta de la negación de un hecho de forma indefinida de carácter absoluto o sustancial, que ocurre, cuando "...no puede ser enunciado y probado por otro afirmativo" (Maturana Miquel, 2015, p. 205).

Una vez cumplido con lo anterior, debemos definir, en segundo lugar, en qué consiste la negación del deudor o la "falta" de entrega de la mercadería o de la prestación del servicio. Decir que "la mercadería no se entregó" o "el servicio no fue prestado" configura una negación indefinida de carácter absoluto o sustancial, que no encierra ninguna afirmación contraria que pueda ser probada por el deudor. En tal caso, si el solicitante insiste y se forma un incidente, corresponderá al acreedor acreditar si el objeto de la prestación fue efectivamente entregado o prestado.

Así se justifica, por último, que el legislador haya establecido mediante la Ley Nº 20.956 (2016) una presunción de entrega o prestación en favor del cesionario, por cuanto anteriormente ésta no existía y le correspondía al acreedor acreditar, según las normas generales de la prueba, el hecho que ahora se presume.

\section{Conclusiones}

Más allá de las diferencias doctrinarias y jurisprudenciales respecto a la naturaleza jurídica de la gestión preparatoria, existen importantes razones para concluir que la gestión preparatoria de notificación de facturas es un juicio propiamente tal. De ello se derivan múltiples consecuencias procesales que se han revisado.

La factura, a su turno, es un título causado que circula haciendo referencia a las mercaderías o servicios que ella describe. En atención a dicho carácter, es posible indagar en la validez de la relación fundamental o subyacente al título, como es la compraventa, prestación de servicios u otra operación similar que contempla la Ley № 19.983 (2004), en caso de impugnación.

Ahora bien, la modificación de la Ley Nº 20.956 (2016) a la Ley Nº 19.983 (2004) impidió impugnar una factura en razón de la falta de entrega de la mercadería o de prestación del servicio durante la gestión preparatoria de notificación de la factura, pero ello no obstaría a indagar en la relación subyacente durante el juicio ejecutivo una vez fallada la vía preparatoria-como título causado que es.

Por lo anterior, no compartimos la solución del legislador mediante la cual ha limitado las excepciones que se pueden hacer valer en un juicio declarativo (la gestión preparatoria), si éstas pueden oponer de todos modos en el ejecutivo. La modificación legal sólo logra retrasar la discusión respecto a la validez del título. 


\section{Referencias Bibliográficas}

Abeliuk Manasevich, R. (2008). Las Obligaciones (5a ed., vol. 1). Santiago: Jurídica de Chile.

Alessandri Rodríguez, A., Somarriva Undurraga, M. y Vodanovic Haklickah, A. (2001). Tratado de las obligaciones (2a ed., vol. 1). Santiago: Jurídica de Chile.

Banco de Chile con Tecnasic S.A (S), Rol. N ${ }^{\circ}$ 35146-2019 (Corte Suprema 10 de septiembre de 2019). Recuperado de https://bit.ly/39PM9Xw

Banco Itaú Chile con Comando de Bienestar del Ejército (E), Rol N 12180-2017 (Corte Suprema 5 de octubre de 2017). Recuperado de https://bit.ly/3hjuF9X

Banco Ripley con Ready Mix Sur S.A., Rol N 526-2011 (Corte Suprema 14 de diciembre de 2011). Recuperado de https://bit.ly/3DNhEiy

Casarino Viterbo, M. (2005). Manual de derecho procesal: derecho procesal civil (2a ed., vol. 3). Santiago: Jurídica de Chile.

Casarino Viterbo, M. (2007). Manual de derecho procesal: derecho procesal civil (6a ed., vol. 5). Santiago: Jurídica de Chile.

CBP Financia Capital Factoring S.A. / LG Electronics Inc. Chile Limitada, Rol N ${ }^{\circ} 7410-$ 2017 (Corte de Apelaciones de Santiago 26 de marzo de 2018). Recuperado de https://bit.ly/3AamYKw

Claro Solar, L. (1979). Explicaciones de derecho civil y comparado (vol. 10). Santiago: Jurídica de Chile.

Código Civil. DFL 1. Fija texto refundido, coordinado y sistematizado del Código Civil; de la Ley № 4.808, sobre Registro Civil, de la Ley № 17.344, que autoriza cambio de nombres y apellidos, de la Ley No 16.618, ley de menores, de la Ley No 14.908, sobre abandono de familia y pago de pensiones alimenticias, y de la Ley № 16.271, de impuesto a las herencias, asignaciones y donaciones. Diario Oficial de la República de Chile, Santiago, Chile, 30 de mayo de 2000. Recuperado de http://bcn.cl/2f6t3

Código de Comercio. Diario Oficial de la República de Chile, Santiago, Chile, 23 de noviembre de 1865. Recuperado de http://bcn.cl/2g7d1

Contemporánea Factoring S.A. con Aserraderos Arauco S.A., Rol N 498-2011 (Corte Suprema 27 de diciembre de 2011). Recuperado de https://bit.ly/38ND4Og

Copia de factura con mérito ejecutivo para su cobro. Requisitos, Rol № 68-2010 (Corte de Apelaciones de Concepción 26 de octubre de 2010). Recuperado de https://bit.ly/3haNb4q 
Cortéz Matcovich, G. (2003). Consideraciones sobre el mérito ejecutivo de la factura. Revista de derecho (Concepción), 71(214). 23-57. Recuperado de https://bit.ly/3kMXH2J

Escobar Saavedra, M. y Hoyuela Zattera, C. (2016). La factura. Un análisis sustantivo del título al tenor de la Ley 19.983 y sus modificaciones. Revista de derecho (Concepción), 84(240), 7-40. Recuperado de https://bit.ly/2YIJanb

Factoring Andino Servicios Financieros S.A. con Import. Export. Stop S.A. (E), Rol N ${ }^{\circ}$ 4714-2017 (Corte Suprema 7 de noviembre de 2017). Recuperado de https://bit.ly/3olFOLZ

Ferretería el Águila Limitada con Logitranss Spa (O), Rol N³8639-2017 (Corte Suprema 26 de julio de 2018). Recuperado de https://bit.ly/3jWua7D

Finameris Servicios Financieros S.A. con Gestión Vial Limitada (E), Rol No 31706-2018 (Corte Suprema 24 de febrero de 2020). Recuperado de https://bit.ly/3z1j4SW

Gómez Balmaceda, R. (2016). La factura comercial y jurisprudencia (Ciclos de Charlas Los Martes al Colegio). Santiago: Colegio de Abogados de Chile.

Historia de la Ley $\mathrm{N}^{\circ}$ 19.983. Regula la transferencia y otorga mérito ejecutivo a copia de la factura. Biblioteca del Congreso Nacional, 04 de mayo de 2018. Recuperado de http://s.bcn.cl/22y4i

Historia de la Ley $N^{\circ}$ 20.323. Modifica la Ley № 19.983 con el objeto de facilitar la factorización de facturas por pequeños y medianos empresarios. Biblioteca del Congreso Nacional, 08 de mayo de 2018. Recuperado de http://s.bcn.cl/1zoug

Historia de la Ley $\mathrm{N}^{\circ}$ 20.956. Establece medidas para impulsar la productividad. Biblioteca del Congreso Nacional, 07 de agosto de 2021. Recuperado de http://s.bcn.cl/1yd0v

Incofin S.A. con Servicio de Salud Valparaíso San Antonio, Rol N 10663-2015 (Corte Suprema 25 de enero de 2016). Recuperado de https://westlawchile.cl id: $\mathrm{CL} / J U R / 680 / 2016$

Interfactor S.A. con I. Municipalidad de Molina, Rol N 17734-2016 (Corte Suprema 13 de septiembre de 2016). Recuperado de https://westlawchile.cl id: CL/JUR/6304/2016

Ley $N^{\circ}$ 1.552. Código de Procedimiento Civil. Diario Oficial de la República de Chile, Santiago, Chile, 30 de agosto de 1902. Recuperado de http://bcn.cl/2f6oc

Ley N ${ }^{\circ}$ 7.421. Código Orgánico de Tribunales. Diario Oficial de la República de Chile, Santiago, Chile, 09 de julio de 1943. Recuperado de http://bcn.cl/2fa3i 
Ley $N^{\circ} 18.092$. Dicta nuevas normas sobre letra de cambio y pagaré y deroga disposiciones del Código de Comercio. Diario Oficial de la República de Chile, Santiago, Chile, 14 de enero de 1982. Recuperado de http://bcn.cl/2k333

Ley $N^{\circ} 19.983$. Regula la transferencia y otorga mérito ejecutivo a copia de la factura. Diario Oficial de la República de Chile, Santiago, Chile, 15 de diciembre de 2004. Recuperado de http://bcn.cl/2f9gu

Ley $\mathrm{N}^{\circ}$ 20.323. Modifica la Ley No 19.983 con el objeto de facilitar la factorización de facturas por pequeños y medianos empresarios. Diario Oficial de la República de Chile, Santiago, Chile, 29 de enero de 2009. Recuperado de http://bcn.cl/2rlt4

Ley $\mathrm{N}^{\circ}$ 20.950. Autoriza emisión y operación de medios de pago con provisión de fondo por entidades no bancarias. Diario Oficial de la República de Chile, Santiago, Chile, 29 de octubre de 2016. Recuperado de http://bcn.cl/2lrgl

Ley $\mathrm{N}^{\circ}$ 20.956. Establece medidas para impulsar la productividad. Diario Oficial de la República de Chile, Santiago, Chile, 26 de octubre de 2016. Recuperado de http://bcn.cl/2k7t2

Ley $\mathrm{N}^{\circ}$ 21.131. Establece pago a treinta días. Diario Oficial de la República de Chile, Santiago, Chile, 16 de enero de 2019. Recuperado de http://bcn.cl/2f6fm

Ley S/N. Efecto retroactivo de la Lei. Diario Oficial de la República de Chile, Santiago, Chile, 7 de octubre de 1861. Recuperado de http://bcn.cl/2rplj

Logros Factoring Spa con Municipalidad de Antofagasta (E), Rol N 16740-2017 (Corte Suprema 8 de noviembre de 2017). Recuperado de https://bit.ly/3BVTH78

Maturana Miquel, C. (2015). Aspectos generales de la prueba. Apuntes de Clases. Departamento Derecho Procesal, Facultad de Derecho, Universidad de Chile.

Morbiducci Ingeniería en Geomensura Limitada con Saldaño Martínez David Kendal.(E), Rol No 6739-2019 (Corte Suprema 3 de enero de 2020). Recuperado de https://bit.ly/3jWJdOz

Palma Rogers, G. (1940). Derecho comercial (vol. 1). Santiago: Nascimento.

Prado Puga, A. (2016). Alcance jurídico de la factura como título mercantil. Revista de derecho (Valparaíso), (46), 155-189. doi: 10.4067/S0718-68512016000100005

Puelma Accorsi, Á. (1984). Letra de cambio y pagaré. Ley $N^{\circ}$ 18.092. Exposición, texto, fuentes y concordancias. Santiago: Jurídica de Chile.

Rabat Celis, F. J. (2002). Procedencia del abandono del procedimiento en la gestión preparatoria de la vía ejecutiva. La preparación de la ejecución: jjuicio o mera ges- 
tión?". Actualidad jurídica (Santiago), (5), 109-120. Recuperado de https://bit.ly/3BARnID

Rebolledo/Figuz S.A., Rol N 508-2019 (Corte de Apelaciones de Chillán 21 de enero de 2020). Recuperado de https://bit.ly/3E1TGjW

Requerimiento de inaplicabilidad por inconstitucionalidad presentado por el Servicio de Salud del Libertador General Bernardo O'Higgins respecto de las frases que indica contenidas en el artículo $3^{\circ}, \mathrm{N}^{\circ} 2$ e inciso penúltimo, y artículo $5^{\circ}$, letra c), de la ley $\mathrm{N}^{\circ}$ 19.983, que regula la transferencia y otorga mérito ejecutivo a copia de la factura, en los autos caratulados "Cumplo Chile S.A. con Servicio de Salud O'Higgins", Rol C32.228-2017, seguidos ante el Primer Juzgado Civil de Rancagua, Rol No 7972-19 (Tribunal Constitucional 7 de mayo de 2020). Recuperado de https://bit.ly/2X9sJtU

Resolución N 8114, Rol N³772-2015 (Corte Suprema 7 de enero de 2016). Recuperado de https://vlex.cl id: 591221650

Resolución N 15456, Rol N 4254-2013 (Corte Suprema 20 de enero de 2014). Recuperado de https://vlex.cl id: 487167042

Resolución N²7342, Rol N³745-2003 (Corte de Apelaciones de Concepción 29 de julio de 2005). Recuperado de https://vlex.cl id: 564355486

Resolución N 150127, Rol N²1197-2015 (Corte Suprema 15 de marzo de 2016). Recuperado de https://vlex.cl id 631541667

Resolución N 170420, Rol № 6301-2012 (Corte de Apelaciones de Santiago 20 de mayo de 2013). Recuperado de https://vlex.cl id: 579517134

Resolución N 192780, Rol N 15318-2013 (Corte Suprema 20 de agosto de 2014). Recuperado de https://vlex.cl id: 524934598

Resolución N² 214494, Rol №1601-2014 (Corte Suprema 17 de septiembre de 2014). Recuperado de https://vlex.cl id: 528691674

Resolución N 544898, Rol № 4253-2015 (Corte de Apelaciones de Santiago 12 de junio de 2015). Recuperado de https://vlex.cl id: 573700110

Resolución N 552845, Rol № 41184-2016 (Corte Suprema 28 de septiembre de 2016). Recuperado de https://vlex.cl id: 650602577

Resolución N 566372, Rol N³5501-2015 (Corte Suprema 4 de octubre de 2016). Recuperado de https://vlex.cl id: 650615437

Resolución N 598646, Rol N³436-2015 (Corte de Apelaciones de Santiago 30 de junio de 2015). Recuperado de https://vlex.cl id: 648058657 
Rioseco Enríquez, G. (2005). Ley 19.983 que regula la transferencia y otorga mérito ejecutivo a copia de la factura. Actualidad jurídica (Santiago), (12), 123-143. Recuperado de https://bit.ly/3DJ9tnw

Román Rodríguez, J. P., Jordán Astaburuaga, L. M., Toro Contreras, P., Morales Zamorano, J., Grebe Lira, F., Asenjo Cheyre, J. F. y Pulido Astorga, A. (2005). Comentarios a la ley que otorga mérito ejecutivo a la factura y su transferencia (Ley No 19.983). Gaceta jurídica (Santiago), (304), 7-30.

Romero Seguel, A. (2009). Curso de derecho procesal civil (vol. 2). Santiago: Jurídica de Chile.

Salas Vivaldi, J. (1986). Situación del Título Ejecutivo en la instancia abandonada. Revista de derecho (Concepción), 54(180), 109-120. Recuperado de https://bit.ly/3BHoggO

Sandoval López, R. (2007) Derecho comercial. Teoría General de los títulos-valores: letra de cambio, pagaré, cheque y títulos electrónicos o desincorporados (5a ed., vol. 2). Santiago: Jurídica de Chile.

Sandoval López, R. (2015). Derecho comercial. Teoría General de los títulos- valores: letra de cambio, pagaré, cheque y títulos electrónicos o desincorporados (vol. 2). Santiago: Jurídica de Chile.

Soc. de Transp. Latino Kunstmann Ltda. con Soc. Frutos del País Frías y Quera Ltda., Rol N $N^{\circ}$ 7.217-2009 (Corte Suprema 7 de diciembre de 2010). Recuperado de https://bit.ly/314986e

Tanner Servicios Financieros S.A. con Fisco de Chile (E), Rol N 39935-2017 (Corte Suprema 16 de abril de 2018). Recuperado de https://bit.ly/3BXQNhY

Valencia Arancibia, A. (2004). Breve análisis de la Ley № 19.983: regula la transferencia y otorga mérito ejecutivo a copia de la factura. Gaceta jurídica (Santiago), (294), 16-21.

Vergara Bezanilla, J. P. (2013). La inoponibilidad de las excepciones en la cesión de créditos expresados en facturas. Revista de derecho - Consejo de Defensa del Estado, (30), 37-44. Recuperado de https://bit.ly/3n0AcGj

\section{Para citar este artículo bajo Norma APA 6a ed.}

Santini Zañartu, G. (2021). Cuestiones procesales de la gestión preparatoria de notificación de facturas. Revista de derecho (Coquimbo. En línea), 28, e3192. https://doi.org/10.22199/issn.07189753-2021-00020 